\title{
Dekada z wieczności. Wizja władzy i jej funkcjonowanie we wczesnym Królestwie Jerozolimskim
}

W artykule pragnę ukazać wizję ustroju, który kształtował się podczas okresu założycielskiego Królestwa Jerozolimskiego i państw krzyżowców. Będę się skupiał na pierwszej dekadzie obecności Franków w Ziemi Świętej i wyjaśnieniu zasad funkcjonowania państwa, istoty władzy, oraz jej ideologii, a także stosunków pomiędzy władzą świecką i duchowną.

Chociaż do naszych czasów nie zachowało się żadne książęce ani królewskie archiwum z czterech państw krzyżowych, mamy dostęp do znacznej liczby akt pochodzących z łacińskiego Wschodu. Zostały one uporządkowane przez Reinholda Röhrichta, a od tamtej pory wypłynęły też nowe źródła tego typu'. Również Hans Mayer wydał monumentalną pracę na temat kancelarii królewskiej w Królestwie Jerozolimy, w której zamieścił dodatkowo kilka nieznanych wcześniej dokumentów² ${ }^{2}$ Cenne źródła zawiera również Kartularz Bazyliki Grobu Świętego. Przetrwały niektóre dokumenty dotyczące klasztorów, głównie z terenu Królestwa Jerozolimskiego. Największą stratą jest oczywiście niezachowanie się archiwum templariuszy. Ocalały natomiast źródła związane z Wenecją, Genuą i Pizą, a także znaczna liczba papieskich listów i dokumentów związanych z Ziemią Świętą. Źródła dotyczące kościołów wydał Rudolph Hiestand, podobnie jak papieskie przywileje dla templariuszy i joannitów.

\footnotetext{
' R. Röchricht, Regesta Regni Hierosolymitani, Innsbruck 1893-1904 [dalej: RRH].

2 H.E. Mayer, Die Kanzlei der lateinischen Könige von Jerusalem, Hannover 1996, s. 887-925.
} 
Dokumenty prawne, pochodzące głównie z XIII wieku, zostały opublikowane przez J. Riley Smitha i P.E. Edbury'ego ${ }^{3}$.

W pracy badawczej dotyczącej prawa i władzy w państwach krzyżowców potrzebne jest sięgnięcie również do źródeł narracyjnych. W swojej pracy skupiłem się przede wszystkim na kronikach opisujących pierwszą wyprawę krzyżową oraz pierwsze lata po zdobyciu Jerozolimy, których autorami są Wilhelm z Tyru, Fulko z Chartres, Albert z Akwizgranu oraz Rajmund z Aguilers.

Grzegorz VII w liście do cesarza Henryka z 7 grudnia 1074 roku wyprawę mającą nieść pomoc chrześcijanom na Wschodzie określa jako akt miłości, oddania życia za braci poprzez obronę prawa Chrystusowego. To prawo Chrystusowe, miłość, jest sensem i przyczyną podejmowania takiego dzieła ${ }^{4}$. Grzegorz VII uważa, że chrześcijaństwo stanowi jedność, zwraca jednak uwagę na kontrowersje i niezgodności pomiędzy Wschodem a Zachodem. W planowanej wyprawie widzi sposobność do rozwiązania tych sporów mocą swojego autorytetu - zarówno jeśli chodzi o filioque, jak i kontrowersje kościoła armeńskiego.

Jednocześnie wyprawa krzyżowa była odpowiedzią na kształtowanie się nowej pobożności i przemian w duchowości. Kiedy Urban II wzywał w Clermont do podjęcia krucjaty, jednocześnie dawał szansę świeckim, aby i oni mogli w doskonały sposób naśladować Chrystusa. Świętość, dotychczas dostępna głównie dla mnichów, teraz była również w zasięgu dla rycerzy. Głodni tej świętości wyruszyli więc z takim zapałem i entuzjazmem. Mieli stać się ,żywą ofiarą, miłą i Bogu przyjemną"5. Znakiem owego poświęcenia stał się krzyż - symbol męki, a z drugiej strony również i bliskości Zbawiciela. Był to wyrazisty znak, że świeccy również mogą naśladować Chrystusa. Kronikarze opisujący zdobycie Jerozolimy akcentowali, że udany szturm miał miejsce w piątek - „dzień w którym Chrystus odkupił cały świat na krzyżu”. Niedługo po tym fakcie miał zostać odnaleziony fragment Krzyża Świętego. Stał się on swoistą relikwią założycielską dla Królestwa Jerozolimskiego, skarbem, który był świadectwem wyjątkowej współpracy człowieka z Bogiem oraz wzajemnej

3 J. Riley-Smith, Feudal Nobility and the Kingdom of Jerusalem, 1174-1277, London 1973; S.W. Edbury, John of Ibelin and the Kingdom of Jerusalem, Woodbridge 1997.

${ }^{4}$ Das Register Gregors VII..., II, 31, s. 165-168. Zob. The Crusades. A documentary survey, oprac. J.A. Brundage, Milwaukee 1962, s. 10n.

${ }^{5}$ Zob. Rz 12,1.

${ }^{6}$ Fulko z Chartres, Historia Hierosolymitana, oprac. Heinrich Hegenmeyer, Heidelberg 1913 [dalej: FC], I, XXVII, 10, s. 299-300; The First Crusade. The Chronicle of Fulko of Charters and other source materials, oprac. E. Peters, Philadelphia 1998, s. 90-91. 
bliskości (thesaurum suum et nostrum ${ }^{7}$ ). Odtąd Prawdziwy Krzyż stał się znakiem i świadectwem zwycięstwa, poczynając od bitwy pod Askalonem aż po Hittin.

Zwołanie krucjaty jest kolejnym krokiem we wprowadzaniu Bożego prawa do chrześcijańskiego świata. Pierwszym było wprowadzanie pokoju i rozejmu Bożego oraz wolności Kościoła. W istocie krok ten w rozumieniu współczesnych polegał na odnowie i przywróceniu pierwotnej czystości. Zaś Urban II miał postrzegać krucjatę w pewnym sensie jako przedłużenie wprowadzania porządku opartego na prawie ${ }^{8}$. Jak opisuje Fulko z Chartres, dzięki Urbanowi II i zwołaniu krucjaty, porządek i ład mogły zostać wprowadzone w całym chrześcijańskim świecie. Rany zadane przez schizmę Wiberta zostały zaleczone?

$$
* * *
$$

Od początku wyprawa krzyżowa była kreowana na wędrówkę narodu wybranego do ziemi obiecanej. Zamiast manny Bóg zsyła krzyżowcom obfite plony i zbiory na całej ziemi, drzewa owocują wyjątkowo obficie, więc niczego nie brakuje tym, którzy oddali się pod Boże rozkazy ${ }^{10}$. Tuż po zdobyciu Nicei, w czerwcu 1097 roku, jeden ze znaczniejszych uczestników krucjaty, Stefan hrabia Blois i Champagne (1089-1102) ${ }^{11}$ pisał w liście do swojej żony Adeli, że zajęcie miasta przez krzyżowców właśnie w owym czasie nie było przypadkowe ${ }^{12}$. Dzięki miłosierdziu Boga pokonali wrogów w rocznicę soboru nicejskiego. Święci ojcowie wówczas odnieśli zwycięstwo nad herezją ariańską i pod przewodnictwem Ducha Świętego potwierdzili prawdę o Świętej Trójcy. Należy też wspomnieć, że Frankowie uważali islam nie za odrębną religię, ale za niezwykle patologiczną herezję. Teraz krzyżowcy pokonali muzułmanów, stając się następcami świętych ojców i wykonawcami Bożej woli ${ }^{13}$.

3.

Jednym z najważniejszych zadań krucjaty miała być pomoc chrześcijanom na Wschodzie i zapewnienie trwałego zjednoczenia. W istocie schizma roku 1054 nie istniała w świadomości współczesnych. Jeden z rycerzy po wymienieniu po-

${ }^{7}$ FC, I, XXX, 4, s. 310.

${ }^{8}$ Zob. FC, I, III, 2, s. 132n.

9 Ibidem, V, s. 143 nn.

${ }^{10}$ FC, I, VI, 2, s. 154. Zob. The First Crusade..., s. 57.

${ }^{11}$ Stefan zginął podczas walk o Ramlę 17 lub 19 maja 1102 roku. Adela, córka Wilhelma Zdobywcy, poślubiła Stefana około 1083 roku. W 1120 roku wstąpiła do klasztoru w Marcigny, gdzie zmarła 8 marca 1137 roku. Listy Stefana do Adeli są interesującym świadectwem zaufania i miłości, którymi darzył swoją żonę.

${ }^{12}$ Epistulae et chartae ad historiam primi belli sacri spectantes. Die Kreuzzugsbriefe aus den Jahren 1088-1100, oprac. H. Hagenmeyer, Innsbruck 1901 [dalej: EC], nr IV, s. 138-40.

${ }^{13}$ Ibidem, s. 140. 
ległych pod Niceą i Antiochią napisał w liście do arcybiskupa Reims: Gaudeat mater Occidentalis ecclesia! quae tales genuit, qui et sibi tam gloriosum nomen adquirerent et Orientali ecclesiae tam mirabiliter succurrerent ${ }^{14}$.

Symeon II, bizantyjski patriarcha Jerozolimy, i Ademar z Monteil, biskup Le Puy i legat papieski podczas wyprawy krzyżowej ${ }^{15} 18$ października 1097 roku napisali wspólnie list, w którym zwracają się do chrześcijańskiego świata w imieniu całego Kościoła na Wschodzie, akcentując swoją jedność. Zaznaczają, że, po pierwsze, modlą się o zbawienie swoich dusz i jest to nadrzędny cel wyprawy. Jednocześnie jest to wezwanie do udzielenia realnej pomocy zbrojnej chrześcijanom, którzy nawet wobec Bożej pomocy czuli się osaczeni przez pogan. Symeon miał doznać wizji, zgodnie z którą każdy, kto zostanie krzyżowcem i pójdzie na wyprawę do Jerozolimy, zostanie przez Boga koronowany w dzień Sądu Ostatecznego ${ }^{16}$. Autorzy listu zaznaczają, że ci, którzy chociaż przyjęli krzyż, nie udali się na Wschód, zostaną ekskomunikowani, jeśli nie przyłączą się wkrótce do wyprawy ${ }^{17}$.

Krzyżowcy zostali powołani by walczyć w miejscu, w którym „walczył sam Zbawiciel”, gdzie „cierpiał za ludzkość” i gdzie „wzywał do naśladowania siebie”. Skoro „Bóg umarł za ludzi”, teraz „ludzie mieli być gotowi zginąc”, lecz za samych siebie, aby nawet jeśli „zginą na tym świecie”, mogli „żyć w Bogu”. W „ziemi żyjących, opływającej w mleko i miód”, mieli zdobyć „podwójną chwałę”. Jak napisał Stefan z Blois, „wybrana armia Chrystusa niepokonana idzie do stolca Pana Jezusa" ${ }^{\prime 18}$.

Po zdobyciu Antiochii Ademar zwołał synod, któremu przewodniczył od czerwca do sierpnia 1098 roku. Przywrócił on wszystkie prawa wobec patriarchatu Antiochii i potwierdził decyzję synodu w Clermont, zgodnie z którą kościoły na terytoriach zdobytych od muzułmanów przez chrześcijańskiego księcia miały należeć do jego domeny ${ }^{19}$. Kiedy rozpoczęła się antiocheńskich kościołów, następnym oczywistym krokiem było ponowne wprowadzenie do nich chrześcijańskich duchownych. Powstał tu dylemat dosyć delikatnej natury. Od wieków głową chrześcijańskiego Kościoła w Antiochii, a więc jego patriarchą, był Grek, grecka była także większość antiocheńskiego duchowieństwa. Patriarcha Jan IV Oksita przebywał podczas pierwszego oblężenia w mieście, a muzułmanie publicznie znieważali go i poddawali torturom. Został oswobodzony, kiedy Antiochia

14 EC, nr VII, s. 145.

15 Ibidem, nr VI, s. 141.

16 Ibidem, s. 142.

17 Loc. cit.

18 Ibidem, nr X, s. 149.

19 G. Bresc-Bautier, Le Cartulaire du chapitre du Saint-Sépulcre de Jérusalem, Paris 1984, nr 89 s. $203-204$. 
skapitulowała. Oczekiwano teraz, że ponownie stanie na czele antiocheńskich chrześcijan - przecież krucjata ogłoszona została z myślą o udzieleniu pomocy Kościołom na Wschodzie. Problem polegał jednak na tym, że księciu Boemundowi byłoby trudniej odmówić Antiochii, gdyby jej patriarchą był grecki biskup. Mimo to z początkiem lipca Jan IV został przywrócony do godności patriarchy, prawdopodobnie właśnie na skutek stanowczych nalegań Ademara z Monteil, który podczas całej wyprawy utrzymywał bliskie stosunki z Kościołem greckim, wypełniając życzenia papieża i wielu uczestników krucjaty. Niepewny, czy cesarz przybędzie do Antiochii, Jan zajął się sprawami kościelnymi i starał się nie mieszać w kwestie związane z polityczną przyszłością miasta. Osiągnięto więc, przynajmniej na jakiś czas, pewien kompromis ${ }^{20}$.

\section{$* * *$}

Tuż po zdobyciu Jerozolimy biskupi i książeta napisali do papieża list, w którym informowali go o zdobyciu Jerozolimy i o wyborze Gotfryda z Bouillon na Obrońcę Grobu Bożego (ecclesiae S. Sepulcri advocatus) ${ }^{21}$. Opisywali w nim cuda, jakich „Armia Boga” doświadczyła w swoim zwycięskim marszu od Nicei do Jerozolimy. Jak zauważają autorzy listu, Jerozolima została zdobyta tylko dzięki pokorze i wierności Bogu. Wcześniej rada złożona z biskupów i książąt zadecydowała, aby wokół miasta przeszła procesja złożona z bosych krzyżowców. Osiem dni później miasto zostało zdobyte. Stało się to w Święto Rozesłania Apostołów. Krzyżowcy widzieli w tym fakcie głęboką symbolikę. W dniu, w którym apostołowie udali się na cały świat, by głosić Ewangelię, krzyżowcy weszli do Jerozolimy, aby zanieść Bożą sprawiedliwość i prawdę wobec tych, którzy zdradzili Boga. Dla krzyżowców oznaczało to niejako domknięcie historii, która miała zmierzać do swej pełni. Kiedy krzyżowcy zdobywali Jerozolimę i umacniali swoją władzę poprzez militarne zwycięstwa, to w istocie cały świat walczył dla nich: pugnabat certe orbis terrarum pro nobis ${ }^{22}$.

Pod koniec lipca 1099 roku Gotfryd z Bouillon poinformował o zdobyciu Jerozolimy i o wybraniu go na króla ${ }^{23}$. W kilka dni później wysłał list do Kościoła na Zachodzie, w którym również informował o wybraniu go jako króla - in regem, jednocześnie prosząc o wszelkie wsparcie dla nowopowstałego królestwa ${ }^{24}$.

${ }^{20}$ EC, s. 249 n.

${ }^{21}$ Ibidem, nr XVIII, s. 167.

22 Ibidem, s. 172.

${ }^{23}$ H.E. Mayer, Die Urkunden der lateinischen Könige von Jerusalem, Hanover 2010 [dalej: Mayer, UKJ], 3:1461-1462, nr II/2 (RRH nr 25).

${ }^{24} \mathrm{EC}, \mathrm{nr} 20$, s. 176 (RRH nr 26). 
Podobnie Arnulf z Chocques poinformował wówczas o swoim wyborze i dołączył się do próśb o pomoc ${ }^{25}$.

Kształt Królestwa Jerozolimskiego dopiero się formował i bez wątpienia ścierały się różne wizje funkcjonowania nowego państwa. Odmowa koronacji przez Gotfryda mogła nie podobać się szczególnie możnym i baronom. Stawiała bowiem pod znakiem zapytania niezależność królestwa. Brak króla, silny wpływ włoskich miast, zagrożenie ze strony cesarza Bizancjum i wreszcie papieskie plany wobec Jerozolimy grozily katastrofą z punktu widzenia ambicji świeckich panów w Outremer. Co ciekawe, Gotfryd niejednokrotnie tytułowany był właśnie królem Jerozolimskim ${ }^{26}$. Bez wątpienia większość towarzyszy Gotfryda pragnęła, aby przyjął on koronę albo był uważany za króla przynajmniej w stosunkach z papiestwem i cesarstwem. Pokora Gotfryda mogła budzić w nich podejrzenie o słabość.

Wilhelm z Tyru w interesujący sposób opisuje wybór Gotfryda z Bouillon na Obrońcę Grobu Bożego ${ }^{27}$. Miało do niego dojść ósmego dnia po zdobyciu Jerozolimy, a więc 22 lipca 1099 roku. Ósmy dzień miał też znaczenie symboliczne jako czas, po którym obrzezano Chrystusa i nadano mu imię ${ }^{28}$; był to dzień ofiarowania pierworodnego Bogu. W kontekście opisu świętowania po zdobyciu Jerozolimy, można ten dzień uważać za ósmy dzień oktawy niezwykłego święta. Książęta zebrali się, aby wybrać jednego spośród nich na władcę, wzywając pomocy Ducha Świętego, podobnie jak przy elekcjach biskupich, czy - sięgając czasów biblijnych - pierwszym tzw. Soborze Jerozolimskim ${ }^{29}$.

Kiedy książęta zebrali się, aby dokonać elekcji, dotarła do nich wiadomość od biskupów i kleru, którzy nie uczestniczyli w obradach. Zwołali oni osobne zgromadzenie, jak komentuje Wilhelm z Tyru, kierowani pychą i troską o własny interes. Wydaje się, że kler świadomy był faktu, iż wizja Ziemi Świętej jako protektoratu papiestwa coraz bardziej się oddala. Próbowali temu przeciwdziałać. Dlatego też pisali w liście: ,jest bez wątpienia prawdą, że sprawy duchowe ważniejsze są od doczesnych i dlatego też należy zająć się nimi jako pierwszymi”. Duchowni pragnęli „zachowania właściwego porządku” i przed wyborem świeckiego władcy żądali dokonania wyboru zwierzchnika Kościoła Bożego, który miał się dokonać w gronie duchownych. Jednocześnie biskupi ostrzegali, że jeśli książęta nie zachowają należytego porządku, wszystko, cokolwiek ogłoszą i uchwalą, będzie bezskuteczne i bez żadnej mocy.

\footnotetext{
25 Ibidem.

${ }^{26}$ Mayer, UKJ 3:1463-1465, nr II/4.

${ }^{27}$ Wilhelm z Tyru, Historia rerum in partibus transmarinis gestarum, IX, 1-2, 5 .

${ }^{28}$ Łk $1,59$.

${ }^{29}$ Por. Dz 15,28.
} 
Odwołali się oni do pojęcia ordo jako swoistego prawa podstawowego. Jest to prawo Boże, część logiki stworzenia. Występowanie przeciwko niemu jest występowaniem przeciwko Bogu. Jednocześnie postanowienia i prawa wydane wbrew niemu właściwie nie istnieją i nie są prawem. Specyficzne warunki krucjaty, kiedy zwyczaje i prawa różnych nacji i grup zderzały się ze sobą, a brak określonych rozwiązań powodował konieczność poszukiwania nowych źródeł rozwiązywania kwestii prawnych, stały się świetną okazją do rozwinięcia idei prawa jako porządku określonego przez Boga i niejako wbudowanego w logikę stworzenia i ekonomię zbawienia.

Wilhelm z Tyru komentuje, że chociaż propozycja biskupów wydaje się sprawiedliwa, to jednak w istocie wynika z pychy Arnulfa, który w ten sposób chciał zdobyć władzę w Jerozolimie i dlatego też należało ją odrzucić. Arnulf miał być człowiekiem złych obyczajów, rozwiązłym, a w dodatku synem księdza. Chciał zostać patriarchą wbrew świętym kanonom i wbrew woli wszystkich sprawiedliwych mężów. Wilhelm opisuje cały ówczesny kler jako zepsuty i szukający jedynie swojego zysku. Bez wątpienia Arnulf był człowiekiem pełnym cech sprzecznych z ówczesną wizją dobrego biskupa. Jednak najważniejsze, czego możemy dowiedzieć się z opisu Wilhelma, to fakt konfliktu pomiędzy dwiema różnymi wizjami funkcjonowania kształtującego się Królestwa Jerozolimskiego.

Zgodnie z wizją duchowieństwa to biskup miał sprawować nadrzędną władzę w Jerozolimie jako obrońca i protektor Kościoła. To on jako jedyny mógł sankcjonować wybór świeckiego władcy, którego władza była niesamodzielna. Zależny od biskupa władca miał przede wszystkim zapewniać wolność Kościołowi, co odpowiadało wizji Grzegorza VII. Jednocześnie Arnulf, jeśli zostałby patriarchą, mógł widzieć siebie w roli kogoś równego papieżowi. Byłby patriarchą jak papież i chociaż Jerozolima nie była biskupstwem św. Piotra, była jednak patrymonium samego Boga. Władca Jerozolimy miał podlegać patriarsze, nie zaś papieżowi.

Jednak książęta zignorowali postulaty kleru. Uważali, że elekcja, której dokonają, zgodna będzie z wolą Boga. Dlatego też wszyscy pod przysięgą zdawali sprawę z wad i zalet każdego z panów i kandydatów na władcę jerozolimskiego. Za najbardziej godnego miał zostać uznany Gotfryd, który procesyjnie, przy śpiewie hymnów i pieśni, został poprowadzony do Grobu Bożego.

Jeśli chodzi o wybór patriarchy Jerozolimskiego, Fulko z Chartres stwierdza, że kanonicy, którzy służyli w kościele Grobu Bożego zdecydowali się nie wybierać patriarchy, dopóki papież nie wyrazi swoich życzeń. Widzi on w kanonikach przypisanych do najważniejszych miejsc chrześcijaństwa organ mogący wybrać patriarchę Jerozolimy. Jednak z uwagi na wyjątkowość miejsca i okoliczności zwraca uwagę na ich uległość wobec woli papieża. Co ciekawe, nie wspomina nic o innych biskupach ani dostojnikach kościelnych przybyłych do Jerozolimy wraz 
z krucjatą. Niedługo później odnotowuje jednak, że Daimbert został wybrany na patriarchę przez księcia i pozostałych dowódców ${ }^{30}$. Podobnie opisany jest wybór biskupa Cezarei ${ }^{31}$. Wydaje się, że w tamtych czasach wybór biskupów należał do władcy, jednak nierzadko był on konsultowany z innymi biskupami, kanonikami i duchownymi. W Królestwie Jerozolimskim próbowano wprowadzić swoistą współwładzę regnum i sacerdotium, którą widać również w nieco późniejszych unormowaniach synodu w Nablusie.

$$
* * *
$$

Jedną z pierwszych decyzji Gotfryda było ustanowienie dwudziestu świeckich kanoników z prebendami w kościele Grobu Bożego w Jerozolimie. Ich prebendy miały być utrzymywane $\mathrm{z}$ datków wiernych ${ }^{32}$. Kościół Grobu Bożego był centralnym miejscem Jerozolimy. Wprawdzie M.C. Gaposchkin uważała, że nie był widoczny specjalny kult Grobu Bożego, lecz cała Jerozolima była równie święta $^{33}$, trzeba jednak zauważyć, że krzyżowcy już od jej zdobycia szczególną uwagę kierowali ku kościołowi Grobu Świętego. Miał on odgrywać kluczową rolę nie tylko jako teologiczne serce chrześcijaństwa, ale miał zostać ściśle powiązany z ideologią władzy w Jerozolimie, którą promował Gotfryd.

W święto Bożego Narodzenia Gotfryd obdarował patriarchę Daimberta dobrami należącymi wcześniej do patriarchy bizantyjskiego i potwierdził wszystkie nowe nabytki ${ }^{34}$. Z jednej strony stanowiło to skutek uznania, że Kościół jest jeden, a różnice między Grekami a Łacinnikami mają jedynie charakter obrzędowy i liturgiczny. Z drugiej jednak łacińscy biskupi wykorzystywali sytuację, by rozciągnąć swoje wpływy i pozbawić bizantyjczyków ich praw i własności.

Sam patriarcha Dagobert tytułował się sługą kanoników Grobu Bożego: S. Sepulcri adiutorum servus ${ }^{35}$. Świadczy to o tym, że w kręgach władzy w Jerozolimie, zarówno tej duchowej jak i doczesnej, ukształtowana była już dosyć konkretna wizja dotycząca ideologii władzy i form jej sprawowania. Kanonicy Grobu Bożego mieli być instytucją nadrzędną, w każdym razie w sensie ideologicznym. Sam zaś patriarcha, i również książę - „Obrońca Grobu Bożego - mieli sprawować swoją władzę niejako poprzez tę instytucję. Specyficzne uwarunkowa-

${ }^{30}$ Ibidem, XXXIII, 20, s. 333.

31 Ibidem, II, X, s. 404-405.

32 Chanson de Jerusalem, oprac. N.R. Thorp, Tuscaloosa 1992, 161, s. 157; P. Riant, Inventaire critique des lettres historiques des croisades, "Archives de l'Orient Latin" 1881, $1 \mathrm{nr}$ 141, s. 199-200 (RRH nr 27).

Albert of Aachen, Historia Ierosolimitana, oprac. S. Edgington, Oxford, 2007 [dalej: AA], s. 454.

${ }_{33}$ M.C. Gaposchkin, Invisible Weapons. Liturgy and the Making of Crusade Ideology, Ithaca 2017, s. 185.

${ }^{34}$ WT, s. 440; Mayer, UKJ 1:99-101, nr 4.

35 EC, nr XXI, s. 176. 
nia Ziemi Świętej skłoniły Gotfryda i Daimberta do próby stworzenia władzy na wzór Kościoła pierwotnego. Kościół rozproszony po całym świecie teraz wracał do swoich początków. Jego zadaniem było też wrócić do swojej pierwotnej czystości. Dlatego też kanonicy Grobu Bożego mieli czuwać oczekując ponownego przyjścia Zbawiciela, tak jak apostołowie oczekiwali zmartwychwstałego Pana i przyjścia Ducha Świętego. Władza w Jerozolimie była w nieodłącznie związana $\mathrm{z}$ eschatologią.

2 lutego 1100 roku Gotfryd podarował kościołowi Grobu Bożego jedną czwartą całego miasta Jaffy ${ }^{36}$. Władza należeć miała do kościoła Grobu Bożego i uformowanej wokół niego wspólnoty, władca doczesny i władca duchowy, tzn. patriarcha, mieli być jej sługami. Dodatkowo liturgia sprawowana w kościele, w szczególności w święto zdobycia Jerozolimy miała być kluczowym „portalem” eschatologicznym ${ }^{37}$.

Natomiast 1 kwietnia 1100 roku Godryf potwierdził wszystkie prawa kościołu Bożego w Jerozolimie. Sam też stał się członkiem wspólnoty tego kościoła: homo Sancti Sepulchri ac noster effectus fideliter deo et nobis se amodo militaturum spopondit $^{38}$. Tego samego dnia Gotfryd podarował patriarsze Daimbertowi, który występował w imieniu kościołu Grobu Bożego, wieżę Dawida i całe miasto Jeruzalem. Uczynił to jednak pod tym warunkiem, że zachowa ich własność, dopóki nie rozszerzy swojej domeny na Stary Kair - Babilon albo inne miasta. Jednak jeśli Gotfryd umarłby bez prawowitego męskiego następcy, Jerozolima i cała Jaffa miała zostać przekazana kościołowi Grobu Bożego ${ }^{39}$. Należy zaznaczyć, że było to niezwykle prawdopodobne wobec faktu, że Gotfryd nie miał żony. Jerozolima cała została ofiarowana Bogu i taki był właściwy sens owej donacji.

W połowie lipca 1100 roku Gotfryd potwierdził wszystkie swoje nadania dla kościoła Grobu Bożego i patriarchy Daimberta w swoim ostatnim testamencie $^{40}$. Uwaga Gotfryda kierowała się jednak nie tylko ku łacinnikom, lecz również ku chrześcijanom innych obrządków. Uwolnił wszystkich Syryjczyków, Ormian, Jakobitów, Nestorian i Greków od podatków, które musieli płacić muzułmanom. Zamiast tego mieli płacić podatek przewozowy i handlowy w wysokości około $1 / 24^{41}$.

${ }^{36}$ WT, s.. 441, 456; Mayer, UKJ 1:101-102, nr 5.

${ }^{37}$ M.C. Gaposchkin, op.cit., s. 131 n.

${ }^{38}$ Wilhelm z Tyru, X, 4, s. 419. WT, s. 456; Mayer, UKJ 1:103-104, nr 7.

39 WT, s. 441, 456; Mayer, UKJ 1:103-104, nr 7 [1]. Zob. FK, s. 741, w odniesieniu do Bożego Narodzenia 1099; także Mayer, Bistümer, Klöster und Stifte im Königreich Jerusalem, Stuttgart 1977, s. 21-37.

${ }^{40}$ WT, s. 456-457; Mayer, UKJ 1:107-108, nr 10.

${ }^{41}$ Francesco Amadi, op.cit., s. 25; Mayer, UKJ 3:1467, nr as.. II/6. 
W tym też czasie Gotfryd z Bouillon miał zakazać podziału lenn bez jednoczesnego podziału powinności, które były z nimi związane. Rozporządzenie to zostało określone jako assise du démémbrement de fief ${ }^{42}$. Filip z Novary uważał, że musiała ona poprzedzać assise de la tenure d'an et jour. Należy jednak pamiętać, że instytucje i prawa królestwa zostały zebrane w traktatach napisanych dopiero po 1187 roku. Ich autorzy wydawali się być ostrożni w odróżnianiu praw zwyczajowych od tych, które ich zdaniem zostały nadane przez władcę ${ }^{43}$ Kiedy byli pewni używali terminu assise, w innych wypadkach mówili najczęściej o zwyczaju.

W celu zapobieżenia powrotom łacińskich osadników do Europy, Gotfryd wprowadził prawo, zgodnie z którym przebywanie w swojej własności przez rok i jeden dzień było konieczne dla nabycia prawa własności do ziemi. Była to już wzmiankowana wyżej assise de la tenure d'an et jour ${ }^{44}$.

Krótkie, trwające zaledwie rok panowanie Gotfryda z Bouillon jest niezwykle interesującym etapem w dziejach Królestwa Jerozolimskiego. Władca, który odmówił przyjęcia korony, miał własną wizję funkcjonowania Franków w Outremer. Jak można zaobserwować w krucjatowych kronikach, listach czy wreszcie aktach prawnych, Gotfryd i krzyżowcy czuli się członkami nowego Narodu Wybranego. Ów nowy Izrael wszedł do nowej Ziemi Obiecanej, która miała być nie tylko ziemskim królestwem, ale prawdziwym apokaliptycznym królestwem Boga z ludźmi. Do tej wizji z Apokalipsy św. Jana Apostoła krzyżowcy niejednokrotnie się odwoływali.

Jednocześnie nie dla wszystkich jasne było, jak wyglądać ma władza świecka i władza duchowna oraz ich wzajemne stosunki w Królestwie Jerozolimskim. Wybierając Gotfryda z Bouillon na władcę, wielu możnych uważało za oczywiste, że koronuje się on na króla. Tak się jednak nie stało. Intersująca jest również rola, jaką Gotfryd wydawał się przeznaczyć kościołowi Grobu Bożego i jego kanonikom. Nie był osamotniony w swoich staraniach, skoro sam patriarcha uznawał się oficjalnie sługą kanoników Grobu Bożego. Ofiarowanie im Jerozolimy było aktem tyleż politycznym, co duchowym i teologicznym.

Równocześnie jednak Gotfryd starał się zapewnić (nie)swojemu państwu sukces militarny i polityczny. Negocjacje z przedstawicielami miast włoskich, listy słane na Zachód z prośbą o pomoc i przybycie krzyżowców, a także prawa dotyczące posiadania lenn miały dać podwaliny do transformacji ruchu krucjatowego

${ }^{42}$ Philip of Novara, Le Livre de Forme de Plait, oprac. Peter Edbury, Nicosia 2009, s. 155; M. Grandclaude, Liste d'Assises remontant au premier royaume de Jérusalem (1099-1187), Paris 1929, s. 335.

${ }^{43}$ Philip of Novara, op.cit., s. 118-120, 179; John of Ibelin, Le Livre des Assises, oprac. P.W. Edbury, Leiden - Boston 2003, s. 684.

${ }^{44}$ WT, s. 446; M. Grandclaude, op.cit., s. 338. 
jako zbrojnej pielgrzymki w realnie istniejące i dobrze funkcjonujące państwo. Nawet jeśli miało być to „Państwo Boże”, Gotfryd miał świadomość, że Bóg będzie rządził nim przez ludzi, przynajmniej w najbliższej przyszłości. Starał się również zapewnić poparcie i jedność wszystkich chrześcijan, poprzez zapewnienie im znacznego obniżenia podatków i zjednoczenia pod jednym patriarchą. Pomoc udręczonym braciom na Wschodzie miała nie być jedynie pustym sloganem. Przywoływana jako jeden z głównych motywów podjęcia krucjaty, okazywała się jednak trudna do wcielenia w życie, szczególnie w obliczu sporów pomiędzy duchownymi różnych obrządków. Należy jednak stwierdzić, że na wielu polach nastąpiło zbliżenie pomiędzy Łacinnikami, Grekami, Ormianami, Syryjczykami oraz chrześcijanami innych obrządków.

Pod koniec lipca 1100 roku główni baronowie królestwa wysłali poselstwo, aby poinformować o śmierci Gotfryda z Bouillon hrabiego Edessy Baldwina z Boulogne, i aby zaprosić go do objęcia rządów w Jerozolimie ${ }^{45}$. Jednocześnie tuż po pogrzebie Gotfryda patriarcha Jerozolimy Daimbert, wysłał posłańca do Boemunda z Tarentu, aby poinformować go o darowiznach nadanych przez Gotfryda dla kościoła jerozolimskiego i jego samego, i o śmierci samego Gotfryda. Informował on również o zajęciu Twierdzy Dawida przez hrabiego Garneriusa, a także o wysłaniu wiadomości do Baldwina. Przedstawił on również późniejsze fakty związane ze śmiercią Garneriusa i kontynuuacją okupowania Twierdzy Dawida, która miała być przekazana Baldwinowi. Apelował on do Boemunda jako zwolennika i propagatora reformy i wolności Kościoła, aby napisał do Baldwina i zabronił mu przybywania do Jerozolimy bez zgody Daimberta. Prosił Boemunda, by zatrzymał Baldwina siłą, jeśli zajdzie taka konieczność ${ }^{46}$. Boemund jednak zaangażowany był w walki z Turkami pod Meliteną, gdzie wspierał swojego ormiańskiego sojusznika, księcia Gabriela ${ }^{47}$.

Patriarcha Daimbert walczył o otrzymanie kruchego stanu rzeczy z czasów panowania Gotfryda z Bouillon. Sam występował niejako w imieniu kanoników Grobu Bożego, bez wątpienia starając się umocnić swoją władzę jako patriarchy. Nie jest już „sługą kanoników”, lecz występuje jako ich prawny reprezentant i realny zwierzchnik. W Tankredzie i Boemundzie szukał on sojuszników, którzy mieli pomóc zachować Kościołowi wolność, a więc mieli spełnić obowiązek sprawiedliwych władców w duchu reformy gregoriańskiej, zapewniając władzy du-

\footnotetext{
${ }^{45}$ AA, s. 528.

46 WT, s.456-458; AA, s. 522 (RRH nr 32).

${ }^{47}$ AA, VII, 28, s. 522-525.
} 
chowej obronę i wolność. Daimbert chciał natomiast występować w roli dziedzica całego Królestwa i dysponenta całości władzy. Jednak mimo testamentu Gotfryda z Bouillon realny układ sił politycznych i sprzeciw większości znaczniejszych możnych w Jerozolimie spowodowały, że szanse na kontynuacje wizji księcia odnośnie królestwa były praktycznie niemożliwe do zrealizowania. W sierpniu 1100 roku Baldwin z Boulogne zaprosił Baldwina Le Bourg, by ten zajął jego miejsce jako hrabia Edessy, sam zaś wyruszył do Jerozolimy ${ }^{48}$.

Baldwin z Boulogne ostatecznie został koronowany na króla w Boże Narodzenie roku 1100. Miejsce narodzenia Chrystusa było uznawane za bardziej właściwe do koronacji niż Jerozolima. Baldwin miał nie czuć się godny nosić korony ze złota i drogich kamieni w miejscu, gdzie Jezus Chrystus - „Król królów i Pan panów" był poniżony i uciskany aż do śmierci dla zbawienia świata oraz ukoronowany koroną z cierni.

Interesujący jest opis objęcia władzy przez Baldwina I. Patriarcha Daimbert nie pojawia się na powitaniu władcy w Jerozolimie, a przez kronikarza oskarżany jest o grzechy zazdrości i nienawiści ${ }^{49}$. W zaledwie rok po zdobyciu Jerozolimy stosunki pomiędzy władzą świecką a duchowną wciąż nie były jasne. Daimbert nadal mógł mieć nadzieję, że w Ziemi Zbawiciela to władza kościelna będzie sprawować realne rządy. Jednak nie posiadał właściwych instrumentów do wprowadzenia w życie owych pomysłów. Książeta dużo łatwiej mogli postawić Kościół wobec faktów dokonanych. Ostatecznie, kiedy następuje koronacja Baldwina I w Betlejem, wybór miejsca również nie jest przypadkowy. Wydaje się, że to patriarcha chciał, aby koronacja władcy odbyła się poza świętym miastem, które ma należeć do władzy duchowej, nie zaś świeckiej. Sam zmarł w drodze z Rzy$\mathrm{mu}$, gdzie zabiegał o pomoc $\mathrm{w}$ walce $\mathrm{z}$ Baldwinem ${ }^{50}$. W jego wizji Królestwo Jerozolimskie miało być państwem Bożym, rządzonym przez arcybiskupa. Papież Paschalis II popierał jego poglądy, nie miał jednak realnych narzędzi, aby w specyficznych warunkach Jerozolimy wprowadzić te idee w życie.

Jednocześnie pierwszym zadaniem Baldwina I jako króla było służenie prawu. Baldwin miał stać się nowym Salomonem, który mądrością miał przewyższać wszystkich innych, dzięki swojej więzi z Bogiem. Baldwin nie był godny nosić korony w Jerozolimie, jednak w tym mieście nade wszystko miał być narzędziem Bożej sprawiedliwości. Kiedy król wymierzał sprawiedliwość podczas pierwszych dni swego panowania przed jego obliczem zjawił się Geldemar. Miał on złożyć skargę przeciwko Tankredowi, który zajął miasto Haifę, przyrzeczoną mu jako dar od księcia Gotfryda za jego służbę wojskową, jeśli zdoła ją zdobyć.

\footnotetext{
48 AA, s. 528-530.

49 FC, II, III, s. 368-369.

50 Ibidem, II, XXVI, 465-468.
} 
Tankred, kiedy usłyszał o śmierci Gotfryda, miał zająć miasto i tym samym sprzeniewierzyć się sprawiedliwości. Właściwie był to kolejny akt w sporze o to, kto może być następcą Gotfryda i jaki kształt miało przybrać królestwo. Kiedy jednak król wysłał poselstwo do Tankreda, ten odpowiedział, że nie uznaje w nim króla ani sędziego Królestwa Jerozolimskiego:

Tancradus autem nullam se de hiis responsionem coram illo habiturum respondit, eo quod nesciret eum regem civitatis et iudicem regni Ierusalem ${ }^{51}$.

Tankred, zgodnie z opisem kronikarza, używa dosyć ciekawej konstrukcji, która może nam wiele powiedzieć o ówczesnym postrzeganiu Jerozolimy i królestwa. Baldwin ma nie być regem civitatis, natomiast wyrażenie to należy rozumieć przede wszystkim w ten sposób, że nie jest on królem miasta Jeruzalem. Miasto Jeruzalem nie jest bowiem tylko miastem. Jest obrazem całego Królestwa Bożego. Jerozolima to Królestwo Boga, rozciągające się na wszystko i wszystkich. Baldwin nie tylko nie może nosić korony w Jerozolimie, ale nie może być też królem, bo uzurpuje sobie tym samym boską władzę. Sprzeciwia się Bogu w najgorszy z możliwych sposobów, jest winny pychy, „korzenia wszelkiego grzechu". Sędzią w Jerozolimie może być dla Tankreda jedynie ten, kto nie sądzi sam, lecz osąd swój poddaje Bogu.

Interesująca była również odpowiedź Baldwina. Wysłał on posłańców przez których zapewniał, że nie uchyla się on od sprawiedliwości. Wzywał on Tankreda, by ten wykazał, co niesprawiedliwego uczynił wobec swojego brata. Baldwin przedstawia prostą doktrynę zgodnie z którą ten jest królem, który zachowuje sprawiedliwość, która rozumiana jest jako wypełnianie ducha, nie zaś litery prawa ${ }^{52}$.

Po długich negocjacjach, kiedy Tankred stanął w obliczu możliwej wojny z Królestwem Jerozolimskim, zgodził się ustąpić. 8 marca 1101 roku król Baldwin I zawarł porozumienie z Tankredem z Hauteville, który wówczas był władcą Antiochii, zgodnie z którym Tankred miał zwrócić władztwa Haify i Tyberiady, jednak pod tym warunkiem, że jeśli przekaże swą władzę w Antiochii (której był regentem po tym, jak odmówił zwrotu księstwa cesarzowi bizantyjskiemu - co wcześniej obiecał Boemund) w ciągu piętnastu miesięcy, jego dobra zostaną mu zwrócone ${ }^{53}$. Tankred uznawał swoją porażkę i niemożność zrealizowania woli Gotfryda z Bouillon. Boemund natomiast wypłacał nagrodę tym, którzy poparli go i wynieśli na tron.

\footnotetext{
${ }^{51}$ AA, VII, 44, s. 552.

${ }^{52}$ AA, VII, 45, s 552.

${ }^{53}$ AA, s.. 552-554; Mayer, UKJ 1:123, nr 19.
} 
Również w marcu 1001 roku kardynał Maurycy z Porto, legat papieski, zwołał w Jerozolimie synod. Była to odpowiedź na zarzuty, jakie wnosił przeciwko patriarsze Daimbertowi król Baldwin do papieża Paschalisa II ${ }^{54}$.

Spór pomiędzy patriarchą a królem stale się zaostrzał. Odwołanie się do papieża było Baldwinowi niezwykle na rękę. W ten sposób z jednej strony dawał papieżowi możliwość wpływu na Królestwo Jerozolimskie i patriarchę, który nie mógł nie poddać się władzy Rzymu. Było to jednocześnie przypomnienie, że idee Daimberta nie mają szans realizacji w rzeczywistości politycznej. $Z$ teologicznego punktu widzenia patriarcha mógł być najważniejszym przedstawicielem władzy duchownej w miejscu spotkania Boga z ludźmi, jednak w istocie nie zmieniało to faktu, że był podległy papieżowi i zależny również od władzy świeckiej.

Król oskarżał patriarchę o krzywoprzysięstwo, zdradę Królestwa Jerozolimskiego i o morderstwo (według niego Gotfryd miał zostać zabity przez Boemunda na drodze między Jerozolimą a Edessą). Został też oskarżony o świętokradztwo na Prawdziwym Krzyżu, którego miał dokonać poprzez jego posiekanie i rozproszenie $^{55}$.

Daimbert został zawieszony w swych prawach patriarchy. Synod został jednak przerwany, a władca doszedł do porozumienia z patriarchą, który obiecał wypłacić mu trzysta bezantów w zamian za doprowadzenie do umorzenia całej sprawy. Król miał przekonywać papieskiego legata, że wycofuje swoje oskarżenia, bo jerozolimski Kościół jest jeszcze młody i słaby, zaś patriarcha nie powinien być pozbawiony swego urzędu w tak wielkie święto, jakim była bliżająca się Wielkanoc, ku zgorszeniu pielgrzymów i uciesze pogan ${ }^{56}$.

Jednocześnie w wypowiedzi króla pojawiają się niezwykle ciekawe słowa, dotyczące tożsamości nowego narodu wybranego. Król mówi bowiem o tym, że legat papieski powinien wysłuchać zdania króla i innych członków Kościoła jerozolimskiego, ponieważ „naszą krwią ten święty Kościół zachowujemy i aż do śmierci za niego walczymy" ${ }^{57}$. Król nie rezygnuje więc z uznania ogromnego teologicznego znaczenia Kościoła jerozolimskiego i roli ludzi w dziele zbawienia. Widoczne tu są bardzo wyraźnie eschatologiczne odniesienia ${ }^{58}$. Niewątpliwie król i elity uważały, że zasługują na wyjątkowe miejsce w Kościele, nie tylko ze względu na bycie członkami wspólnoty w tak wyjątkowym miejscu, jakim była Jerozolima, ale przede wszystkim z uwagi na swoje własne czyny. Upodobnili się do Zbawiciela, oddając swoje życie w Jerozolimie Bogu. Bóg posługuje się nimi tak, jak niegdyś posłużył się swoim Synem.

\footnotetext{
${ }^{54}$ AA, VII, 45, s. 554

${ }_{55}$ AA, VII, 48, s. 556.

56 AA, VII, 50, s 558.

57 Ibidem.

${ }^{58}$ Ap 2,10, Ap 12, 9-11.
} 
Wydarzenia te miały miejsce przed Wielkanocą, kiedy Daimbert chciał dokonać poświęcenia świętych olejów w Wielki Czwartek na Górze Oliwnej. W opisie kronikarza fakt, że do pojednania doszło przed Świętami Wielkanocnymi, jest niezwykle istotny. Pojednanie władzy duchownej ze świecką było niezbędnym warunkiem dla pokoju i bezpieczeństwa. Zjednoczone królestwo mogło doznawać łaski Boga, wolności od wrogów zewnętrznych i wewnętrznych, w pełni czerpiąc z zasług świętego miasta ${ }^{59}$.

Otwierał się jednak nowy rozdział w stosunkach pomiędzy władcą a Kościołem. Patriarcha musiał uznać swoją polityczną porażkę, wciąż jednak liczył na zachowanie tronu patriarchy. Mimo osobistej przyjaźni z legatem papieskim ${ }^{60}$ miał świadomość, że Kościół jerozolimski wobec nieprzejednanej postawy Baldwina i jego mocnej pozycji nie jest w stanie spełniać roli nadrzędnej wobec władzy doczesnej.

Ostatecznie Baldwin wygrał swój spór z patriarchą Daimbertem, który poniósł całkowite polityczne fiasko. W obecności legata papieskiego wizja królestwa Jerozolimskiego jako królestwa ducha, którym władają władcy duchowi, odchodziła w niepamięć. Wizja ta była już zszargana i wypaczona przez intrygi i polityczne działania Daimberta i nie miała wiele wspólnego z pierwotnymi ideałami Gotfryda. Nowy legat papieski, kardynał Robert od Świętego Euzebiusza, sądził Daimberta oskarżonego przez niektórych o symonię, przez innych o morderstwo greckich chrześcijan w Kefalonii, które Genueńczycy mieli popełnić na jego rozkaz, inni oskarżali go o zdradę króla Baldwina, niektórzy zaś o sprzeniewierzenie pieniędzy i ofiar wiernych, które miał ukrywać dla własnych korzyści. Daimbert został uznany winnym, usunięty z urzędu i ekskomunikowany. Na jego miejsce zaś wybrany został Ewremar ${ }^{61}$.

Słowa opisujące patriarchę Ewremara jako z jednej strony sługę Boga w świątyni jego Grobu, z drugiej zaś strony jako oddanego pomocnika (adiutor) króla Baldwina w walce $z$ Saracenami i niewierzącymi najlepiej oddają sytuację, w jakiej znalazł się Kościół w Jerozolimie. Ciągła walka o tron patriarszy powodowała osłabienie władzy duchowieństwa. Zyskiwał król, który umiejętnie wykorzystywał Stolicę Apostolską do utrzymywania kontroli nad obsadą i kształtem patriarchatu.

W kilka lat później wybuchł spór pomiędzy Ewremarem a Arnulfem z Chocques. Ewremar podnosił swoje prawa do Jerozolimy jako wybrany kanonicznie na patriarchę Jerozolimy, jednak archidiakon Arnulf nie chciał ustąpić, dlatego też papież zdecydował się wysłać kolejnego swojego legata, Gibelina z Arles, który

\footnotetext{
${ }^{59}$ AA, VII, 51, 560.

${ }^{60}$ Ibidem.

${ }^{61}$ AA, IX, 16-17, s. 656-658.
} 
miał rozwiązać całą sprawę ${ }^{62} .4$ grudnia 1106 roku papież Paschalis II napisał list, w którym zwracał się do króla Baldwina I, duchowieństwa i ludu Jerozolimy. Kościół jerozolimski doznał zgorszenia, najpierw za sprawą Daimberta, teraz zaś znów za sprawą Ewremara. W pierwszej połowie 1108 roku synod w Jerozolimie, odbywający się pod przewodnictwem papieskiego legata, potwierdził decyzję papieża o usunięciu Ewremara z patriarchatu. Jednocześnie Ewremar został wyniesiony na arcybiskupstwo w Cezarei ${ }^{63}$.

Zimą 1009/1010 został wznowiony kościelny synod, który po raz pierwszy obradował na początku 1008 roku. Gibelin z Arles został wybrany na nim patriarchą. To symboliczna data podsumowująca pierwszą dekadę istnienia Królestwa Jerozolimskiego. Jest nią z kilku powodów. Gibelin, konsekrowany na biskupa jeszcze przez Grzegorza VII, zajmując miejsce Ewremara, był wyraźnym znakiem sukcesu polityki królewskiej. Król umiejętnie wykorzystywał papiestwo, wysuwając oskarżenia wobec swoich politycznych przeciwników. Wybór Gibelina był też fiaskiem lokalnych elit duchowieństwa, które nie było w stanie przedstawić własnego kandydata, który mógłby zostać wybrany biskupem. W istocie było to potwierdzeniem zależności Kościoła od króla. Idea prymatu władzy duchownej w Jerozolimie okazała się mrzonką.

Jednocześnie jednak wszystko zależało od punktu widzenia. W wyjątkowych uwarunkowaniach Ziemi Świętej granice między władzą doczesną i władzą duchowną były postrzegane zupełnie inaczej. Zarówno król, jak i patriarcha byli obarczeni obowiązkami i odpowiedzialnością znacznie wykraczającymi poza tradycyjny podział tych władz. Widać to wyraźnie nie tylko w dokumentach i kronikach z państw krzyżowców, ale również w listach biskupów i papieży, wysyłanych na Wschód. Król i patriarcha mieli razem prowadzić Kościół walczący i triumfujący do Niebiańskiej Jerozolimy. W układzie sił politycznych po pierwszym dziesięcioleciu zdecydowanie przeważał król, zupełnie inna była jednak optyka teologiczna.

$* * *$

Gibelin z Arles umarł w dwa lata później, zaś jego miejsce zajął ostatecznie powracający na tron patriarszy po kilkunastu latach Arnulf. Patriarchatem zaczęły wstrząsać wtedy potężne skandale związane ze stylem życia patriarchy.

Za swoisty epilog podsumowujący pierwsze lata istnienia łacińskiego patriarchatu w Jerozolimie można uznać proces Arnulfa, patriarchy jerozolimskiego, który został oskarżony o symonię, prowadzenie rozwiązłego trybu życia i nie-

\footnotetext{
${ }^{62} \mathrm{PK}, \mathrm{s.104-107, \textrm {nr }} 8$ (RRH nr 49).

${ }^{63}$ WT, s. 501 (RRH nr 50). Wilhelm z Tyru, XI, 4.
} 
zgodne z prawem kanonicznym uznanie i pobłogosławienie trzeciego małżeństwa Baldwina I. Na początku 1115 roku synod kościelny, któremu przewodniczył Berengar, biskup Orange i legat papieski, odwołał z urzędu patriarchę uznając go winnym symonii. Arnulf odwołał się jednak do samego papieża ${ }^{64}$.

19 lipca 1016 roku papież Paschalis II napisał list informujący króla, Kościół Jerozolimski: zarówno duchownych, jak i świeckich, o swoim wyroku w sprawie patriarchy Arnulfa, który miał być reakcją na oskarżenia o pochodzenie z nieprawego łoża, stosunki seksualne z kobietami oraz o to, że zamiast w wyniku kanonicznego wyboru, został ustanowiony patriarchą Jerozolimy przez króla Baldwina ${ }^{65}$.

Liderem grupy oskarżycieli był arcybiskup Cezarei Ewremar, który na świadków powołał dwie kobiety, z której jedna miała być muzułmanką - Sarracena. Papież wysłał swojego legata na Wschód. Arnulfa oraz wielu innych jego „braci biskupów” wezwano do Włoch. Papież zauważa, że dotarło do niego wiele listów z prośbą o uwolnienie Arnulfa od wszelkich zarzutów i udzielenie mu dyspensy jako dziecku z nieprawego łoża. Pojawiły się liczne protesty przeciwko rzekomo stronniczej decyzji papieskich legatów. Za Arnulfem wstawili się zarówno król, biskupi, opaci, jak i liczni inni duchowni Królestwa Jerozolimskiego. Możni duchowni złożyli przysięgę, że wybrali Arnulfa na patriarchę jerozolimskiego bez strachu przed przemocą ze strony króla. Również Arnulf przysiągł, że nie jest winny żadnych przestępstw. Dlatego też papież przywrócił Arnulfowi patriarchat Jerozolimy. Jednocześnie jako uzasadnienie dyspensy przywołał cytat z Pierwszego Listu Świętego Piotra: ,albowiem miłość zakrywa wiele grzechów" $"$.

\section{5.}

Jan z Ibelinu napisał jeden z najobszerniejszych traktatów prawnych średniowiecza. W jednej z ksiąg swojego dzieła, powstałego w połowie XIII wieku i znanego jako Le Livre des Assises, przedstawił istotę władzy w Królestwie Jerozolimskim:

W Królestwie Jerozolimskim jest dwóch władców: jeden duchowy drugi zaś doczesny. Patriarcha Jerozolimy jest władcą duchowym, zaś król Królestwa Jerozolimskiego jest władcą doczesnym ${ }^{67}$.

\footnotetext{
${ }^{64} \mathrm{RRH}, \mathrm{nr} 81$.

${ }^{65}$ E. de Roziere, op.cit. nr 11, s. 11.

661 P 4,8 .

${ }^{67}$ John of Ibelin, op.cit., 225, s. 590.
} 
Od początku istnienia Królestwa Jerozolimskiego ścierały się różne wizje jego funkcjonowania, natury oraz istoty władzy. Nie udało się zrealizować idei papieża - Królestwa Jerozolimskiego jako protektoratu biskupstwa rzymskiego. Jednak również wizja części elit krucjatowego duchowieństwa, która widziała w Jerozolimie stolicę biskupią równą Rzymowi, w której władca doczesny podporządkowany będzie władcy duchownemu, nie przetrwała starcia z rzeczywistością. Jednocześnie książętom świeckim nie udało się zrealizować twardej polityki przedgregoriańskiej i podporządkować Kościoła władzy doczesnej.

Stosunkowo silna, jak na średniowieczne warunki, władza królewska, zupełnie inaczej postrzegana była przez obserwatorów z innych kręgów kulturowych. Niezwykle interesujące wydaje się muzułmańskie spojrzenie na króla, władzę i sądownictwo Franków. Usama ibn Munikdh w swojej Księdze Pouczających Przykładów przytoczył taką opowieść:

Frankowie - niech ich Allah opuści - nie posiadają innej cnoty oprócz dzielności, lecz rycerze mają u nich pierwszeństwo i wysoką pozycję; nikt u nich nie jest ceniony tak, jak rycerze. Oni to wydają opinie, sądy i decyzje. I tak pewnego razu poprosiłem ich o sprawiedliwe wydanie wyroku w sprawie stada owiec, które zajął w lesie pan miasta Benijas. Między nami a Frankami panował wówczas pokój i ja przebywałem w Damaszku. Powiedziałem królowi Fulko, synowi Fulka: „On postąpił niesprawiedliwie - zajął nasze zwierzęta wówczas, kiedy owce mają jagnięta; jagnięt urodziły się i padły zaraz. Oddał nam owce bez jagniąt”. Król wtedy powiedział do sześciu, siedmiu rycerzy: „Powstańcie i wydajcie wyrok w tej sprawie!”. Oni wyszli z sali posiedzeń i naradzali się na osobności tak długo, aż doszli do zgodnej opinii. Potem powrócili do sali posiedzeń króla i rzekli: „Zdecydowaliśmy, że władca Banijas powinien wynagrodzić im to, co stracili”. I król rozkazał wypłacić mu to odszkodowanie. Lecz ten zwrócił się do mnie, molestował i błagał dopóty, dopóki nie przyjąłem od niego czterystu dinarów. Takie postanowienie, na które zgodzą się także rycerze, nie może być zmienione ani przez króla, ani przez nikogo spośród książat Franków. Albowiem rycerz u nich to wielka rzecz ${ }^{68}$.

Pierwsze lata po zdobyciu Jerozolimy to czas ogromnej euforii. Krzyżowcy odnosili zwycięstwo po zwycięstwie nad podzielonymi władcami w Palestynie. Nie były to jednak zwycięstwa łatwe, a rozsądek polityczny i wojskowy książąt mimo wszystko nie został stępiony przez kolejne trumfy.

Zdobycie Jerozolimy miało być punktem kulminacyjnym dla historii świata, swoistym nowym początkiem, miała rozpocząć się wieczna wiosna świata. Krucjata która była, jak określiła ją M.C. Gaposchkin, „klasztorem w drodze”, ${ }^{69}$

${ }^{68}$ Kitab al I’tibar: Księga pouczajacych przykładów dzieło Usamy ibn Munkidha tj. Muajjada ad-Daula abu Muzaffara Usamy ibn Murszida ibn Ali ibn Mukallada ibn Nasra ibn Munkidha al-Kinani asz-Szajzari, oprac. J. Bielawski, Wrocław 1975, s. 130-131.

${ }^{69}$ M.C. Gaposchkin, op.cit., s. 94. 
krzyżowcy zaś mieli być „czasowymi mnichami”70. W istocie jednak bycie krzyżowcem oznaczało znalezienie się w samym sercu misji chrześcijaństwa, być krzyżowcem znaczyło być prawdziwym chrześcijaninem, to znaczy drugim Chrystusem.

Krzyżowcy byli prawdziwymi Izraelitami ${ }^{71}$. Stary Testament miał być tylko zapowiedzią nowej wędrówki do Jerozolimy. Dla krzyżowców Nowy Testament nie był zamkniętą księgą, lecz dzieło Boga wciąż trwało i wypełniało się właśnie poprzez nich, swoistych współodkupicieli świata.

Dlatego też pierwsze lata po zdobyciu Jerozolimy były swoistym adwentem, oczekiwaniem na Tego, który wszystko miał uczynić nowe. Skutkiem tych idei była postawa Gotfryda, który nie przyjął korony, lecz skupił się na tworzeniu wspólnoty wokół Grobu Bożego, mającej uosabiać Kościół czuwający. Władza duchowa i władza doczesna miały połączyć się na Ziemi, by każde stworzenie dostąpiło też połączenia z Jerozolimą Niebiańską.

Interesująca jest niezwykła i specyficzna pasja jedności w różnorodności, którą można uchwycić w różnych dziełach podejmowanych podczas krucjaty i po jej zakończeniu. Ścisła jedność wiernych różnych obrządków, uwolnienie wszystkich chrześcijan od niesprawiedliwości (również tej ekonomicznej), jedność władzy świeckiej i duchowej, nieustanna wspólna modlitwa i stałe czuwanie w oczekiwaniu na przyjście Pana to idee, którym poświęcono wiele politycznej i teologicznej energii.

Jednocześnie zarówno Gotfryd, jak i Baldwin energicznie zajmowali się polityką wewnętrzną i militarną swojego państwa. Odnosili liczne zwycięstwa militarne, umacniając obecność Franków w Ziemi Świętej. Równie skuteczne okazywały się układy i sojusze z często zwaśnionymi ze sobą władcami muzułmańskimi. Baldwin I okazał się sprawnym politykiem, który potrafił podporządkować sobie swoich przeciwników, zarówno możnych, jak i duchowieństwo. Paradoksalnie papiestwo okazało się sojusznikiem Baldwina, który pod pewną przykrywką realizowania idei reformatorskich papiestwa, zapewniał sobie dużą władzę nad Kościołem Jerozolimskim, który swe pierwotne plany supremacji władzy duchownej zamienił na wewnętrzne waśnie, spory i skandale.

Jednak najlepszym podsumowaniem dążeń i planów krzyżowców, są słowa Wilhelma z Saint Thierry:

A więc, Ty, którego prawdziwie szukający nie może nie znaleźćc ${ }^{2}$, zwłaszcza że sama prawda szukania Ciebie w sumieniu szukającego ma niewątpliwy odzew prawdy jakoś odnale-

\footnotetext{
${ }^{70}$ Ibidem, s.211.

71 Ibidem, s. 183.

${ }^{72} \mathrm{Mt}$ 7,7.
} 
zionej, znajdź nas, abyśmy mogli znaleźć Ciebie. Przyjdź do nas, abyśmy mogli przyjść do Ciebie i żyli w Tobie, ponieważ naprawdę to nie zależy od chcącego ani od ubiegajacego się, ale od Twojego miłosierdzia ${ }^{73}$. Ty pierwszy nas pobudzaj, abyśmy wierzyli, umacniaj nas, abyśmy mieli nadzeję, kieruj nami i rozpal nas, abyśmy miłowali. Wszystko nasze niech będzie Twoje, abyśmy szczęśliwie byli w Tobie, w którym „żyjemy, poruszamy się i jesteśmy"74.

\title{
DECADE OF ETERNITY. THE VISION OF POWER AND ITS FUNCTIONING IN THE KINGDOM OF JERUSALEM
}

\begin{abstract}
The article describes the vision of power and its functioning during the first decade of the Crusader states. The crux of the paper is the essence and theological meaning of the Crusade as well as the eschatological role of Jerusalem. These issues have an immense influence on the understanding of the concept of power and its realization. The Crusaders perceived themselves as the new Chosen People as they considered themselves co-redeemers of the world. They were supposed to bring about the Second Coming of Jesus Christ by seizing Jerusalem. The result of these ideals was Godfrey's attitude who did not accept the crown. He rather concentrated on the creation of a community around the Holy Sepulchre which was to embody the guardian Church. At the same time, both Godfrey and Baldwin dealt with domestic policy and military policy in an efficient manner. Paradoxically, the Papacy turned out to be Baldwin's ally. He secured a lot of influence and power over the Church of Jerusalem under the cover of realizing the reformative ideas of the Papacy. The original plans pertaining to the supremacy of the Church turned into internal feuds, quarrels and scandals.
\end{abstract}

\section{DECENNIE D'ETERNITE. VISION DU POUVOIR ET SON FONCTIONNEMENT DANS LE ROYAUME DE JERUSALEM}

\section{Resumé}

Le présent ouvrage porte sur la vision du pouvoir et de son fonctionnement lors de la première croisade et de la première décennie d'existence des États de croisés. Il se concentre sur l'essence et la signification théologique de la croisade et sur le rôle eschatologique de Jérusalem qui ont l'influence considérable sur la compréhension du pouvoir et de son exercice. Les croisés se sont compris comme le nouveau Peuple élu, se considérant comme une sorte de co-rédempteurs du monde. Par la conquête de Jérusalem, ils mèneraient à la venue de Jésus Christ. Le résultat de ces idées fut l'attitude de Godefroy qui n'accepta pas la couronne mais se concentra sur la création d'une communauté autour du

\footnotetext{
${ }^{73}$ Por. Rz 9,16.

${ }^{74}$ Dz 17,28. Wilhelm z Saint Thierry, Zwierciadto wiary, 122, s. 172.
} 
Tombeau de Dieu, censée personnifier l'Église vigilante. Dans le même temps, Godefroy et Baldwin ont exercé de manière efficace la politique interne et militaire de leur pays. Paradoxalement, la papauté s'est avérée être un allié de Baldwin qui, sous couvert de concrétiser les idées réformistes de la papauté, s'est acquis un grand pouvoir sur l'Église de Jérusalem ; et cette dernière a transformé son projet initial de suprématie du pouvoir spirituel en conflits internes, querelles et scandales. 